\title{
11 When Nationalism Meets Soft Skills
}

\author{
Towards a Comprehensive Framework for Explaining \\ Ethno-migrant Inequality in the Dutch Labour Market
}

\author{
Hans Siebers
}

\begin{abstract}
The aim of this chapter is to outline a framework of explanation. Why is it so difficult for people with a 'non-Western' background to participate in the labour market on equal terms with people without a migration background? There are different ways of structuring the various explanations in the literature. On the one hand, inspired by Bourdieu, Siebers will distinguish various forms of capital - human, social, cultural - that may give access to economic capital, such as getting a well-paid or satisfying job. On the other hand, Siebers will discuss indirect discrimination when non-job-related capitals, such as social and cultural capital, play a role in harming the chances for people with a 'non-Western' migration background to access economic capital.
\end{abstract}

Keywords: soft skills, Bourdieu, forms of capital, non-Western migration background

\section{Introduction}

Ethno-migrant inequality in the labour market is a persistent problem in many countries. ${ }^{1}$ In the Netherlands, especially people with a first- or

1 A. Heath and S. Y. Cheung (2007), Unequal Chances: Ethnic Minorities in Western Labour Markets, Oxford: Oxford University Press; F. van Tubergen, F. Maas, and H. Flap (2004), 'The economic incorporation of immigrants in eighteen western countries: Origin, destination, and community effects', American Sociological Review 69(5) pp. 704-727.

Rijken, Conny and Tesseltje de Lange (eds): Towards a Decent Labour Market for Low Waged Migrant Workers. Amsterdam: Amsterdam University Press, 2018 DOI: $10.5117 / 9789462987555$ SIEB 
second-generation 'non-Western' migration background ${ }^{2}$ find themselves in subordinated positions in the labour market. Their unemployment rates in particular, are a matter of great concern. In the first quarter of 2017, their unemployment rate was 12.8 percent, compared to 4.4 percent of the nonmigrant population. ${ }^{3}$ This factor of three of having higher chances of becoming unemployed if you have a migration background, than if you do not, has been visible and consistent for several decades already. This problem cannot be attributed to nationality. Unemployment rates amongst people with a second-generation 'non-Western' background (45 percent of the total population with a 'non-Western' migration background) are even higher (17 percent) than those belonging to the first generation (14 percent), even though many people of the second generation have Dutch nationality. ${ }^{4}$

At the meso level, these macro figures are reflected in findings of a number of case studies we carried out in the Dutch public sector. ${ }^{5}$ In these organisations, people with a 'non-Western' background are underrepresented in the labour force. If they have a job, these jobs are usually low-waged and on the lower job levels. Having a 'non-Western' migration background, or

2 Dutch classification systems define someone as having a migration background if at least one of his or her parents was born abroad. That includes first- and second-generation migrants. Subsequently, this classification differentiates between origins: so-called 'Western' and 'nonWestern' parts of the world. 'Non-Western' includes Latin America, the Caribbean, Africa, the Middle East, Turkey, and Asia (except Japan and Indonesia). Other parts are seen as 'Western'. This classification is based on a combination of assumed economic progress and assumed cultural difference, with the Netherlands presumably being closer to the 'West' than to 'non-Western' parts of the world. See: http://statline.cbs.nl/Statweb/publication/?DM=SLNL\&PA=82809NED $\& \mathrm{D}_{1}=\mathrm{a} \& \mathrm{D}_{2}=0 \& \mathrm{D}_{3}=0 \& \mathrm{D}_{4}=\mathrm{a} \& \mathrm{D}_{5}=\mathrm{l} \& \mathrm{VW}=\mathrm{T}$

3 Cbs.statline.nl.

4 CBS (2016), Jaarrapport Integratie 2016, Den Haag/Heerlen: Centraal Bureau voor de Statistiek.

5 See H. Siebers (2009a), '(Post)bureaucratic organizational practices and the production of racioethnic inequality at work', Journal of Management and Organization, 15(1), pp. 62-81; H. Siebers (2009), 'Struggles for Recognition: The Politics of Racioethnic Identity among Dutch National Tax Administrators', Scandinavian Journal of Management, 25(1), pp. 73-84; H. Siebers (2010), 'Organisatiecultuur en verhulde discriminatie: Over het onthullen van discriminatie in hedendaagse organisaties', in C.J. Forder (ed.), Gelijke Behandeling: Oordelen en Commentaar, Nijmegen: Wolf Legal Publishers; H. Siebers (2010), 'The Impact of Migrant-Hostile Discourse in Media and Politics on Racioethnic Closure in Career Development in The Netherlands', International Sociology 25(4) pp. 475-500; H. Siebers (2017), 'What turns migrants into ethnic minorities at work? Factors erecting ethnic boundaries among Dutch police officers', Sociology 51(3), pp. 6o8-625; H. Siebers and M.H.J. Dennissen (2015), 'Is it cultural racism? Discursive oppression and exclusion of migrants in the Netherlands', Current Sociology63(3), pp. 470-489; H. Siebers and J. van Gastel (2015), 'Why migrants earn less: In search of the factors producing the ethno-migrant pay gap in a Dutch public organization', Work, Employment and Society 29(3), pp. 371-391. 
not, makes a difference in recruitment, hiring decisions, access to higher job levels, fair pay, development opportunities, promotion chances, and so on.

The aim of this chapter is to outline a framework of explanation. Why is it so difficult for people with a 'non-Western' background to participate in the labour market on equal terms with people without a migration background? There are different ways of structuring the various explanations in the literature. On the one hand, inspired by Bourdieu ${ }^{6}$, I will distinguish various forms of capital - human, social, and cultural - that may give access to economic capital, such as getting a well-paid or satisfying job. On the other hand, I will discuss indirect discrimination when non-job-related capitals, such as social and cultural capital, play a role in harming the chances for people with a 'non-Western' migration background to access economic capital. Direct discrimination is apparent when these people's access to economic capital is directly diminished or when their capital is depreciated - Bourdieu uses the term symbolic violence here.

The chapter first discusses human capital, social capital, and discrimination, drawing on existing explanations in the literature. Next, my own contributions to the literature will be presented. I will demonstrate the impact of nationalist discourses in media and politics on relations between nonmigrant employees and applicants, and their colleagues with a 'non-Western' migration background. I will also develop a cultural capital understanding of 'soft skills' requirements to understand how they exclude people with a 'non-Western' migration background in the labour market. I will highlight how 'soft skills' requirements converge with Dutch nationalism to fuel discrimination against people with a 'non-Western' migration background in Dutch work settings.

I will do so with a broad view drawing on research projects carried out in Dutch organisations, including the Dutch police; the Dutch tax administration; The Hague University of Applied Sciences; the provincial administration of Noord-Holland; the Dutch ministry of Agriculture, Nature and Food Quality; the Dutch ministry of Education, Culture and Science; Deloitte; and the municipality of Eindhoven. Most of these projects combine a meso perspective (questionnaires and document analysis) with a micro focus on everyday interactions and experiences (observations and interviews).

They start with exploring the mechanisms and factors that may produce unequal chances in, for example, getting a job, fair promotion chances, and pay.

6 P. Bourdieu, (1977), Outline of theory of practice, Cambridge: Cambridge University Press. ; P. Bourdieu, (1984), 'Social space and symbolic power', Sociological Theory 7(1), 14-25; P. Bourdieu, (1986), 'The forms of capital', in J Richardson (ed.) Handbook of Theory and Research for the Sociology of Education, Westport, CT: Greenwood. 
That means doing observations or asking respondents to keep a diary on their daily experiences, and conducting interviews with mixed samples of employees, applicants, supervisors, and selectors with nonmigration and 'non-Western' migration backgrounds to allow for comparison. Usually, we focus on triads of employees or applicants with similar characteristics in terms of gender, age, education, and work experiences, one being a nonmigrant and the other one having a 'non-Western' migration background, and their supervisor or selector.

Subsequently, the representativity of these explorative findings is assessed based on distributing questionnaires amongst all employees and applicants. These findings are used for building models through structural equation modelling, to explain inequality between nonmigrant and 'non-Western' migrant respondents in access to economic capital like jobs, promotions, pay, etc. statistically.

That means that these projects are about those people with a migration background who are relatively well-off. The civil servants who work in public organisations have permanent residency rights, and, in most cases, also Dutch nationality. They have also had access to formal education, most of them at middle- or higher-education levels in the Netherlands. These people are not in the most precarious positions, like the undocumented migrants discussed by Berntsen \& de Lange and Della Torre, the seasonal workers discussed by Herzfeld Olsson and Zoeteweij, or most of the intra-EU migrant workers discussed elsewhere in this volume.

Nevertheless, many of these civil servants with a 'non-Western' migration background were born from parents who came to the Netherlands in the second half of the previous century, often living and working in precarious positions. They currently face factors and mechanisms that have a negative impact on their chances to get a job, and to receive compensation appropriate to their qualifications: they face ethno-migrant inequality.

\section{Ethno-migrant Inequality}

The term ethno-migrant inequality ${ }^{7}$ is used here since it is often unclear whether the inequality and the exclusion processes migrants face are due to their migration status or to them becoming the object of ethnicisation. For example, migrants may have less contact with influential people who may

7 H. Siebers and J. van Gastel (2015), 'Why migrants earn less: In search of the factors producing the ethno-migrant pay gap in a Dutch public organization', Work, Employment and Society 29(3), pp. 371-391. 
help them to get a job. That may be due to their recent arrival (migrancy status) having had little time so far to develop such contacts. However, fewer contacts may also result from the processes of ethnicisation when they are identified as people who represent a particular ethnic group with different cultural characteristics. ${ }^{8}$ Such ethnic identification may induce nonmigrants to consider them to not belong to their own group, and thus to avoid contact with them. It is difficult for migrants to network at a reception when no one wants to talk with them. Such contact avoidance means that ethnicity is salient and operational. On many such issues, we have insufficient knowledge about what is at stake, 'migrancy'9 or ethnicity. Therefore, the provisional term ethno-migrant inequality is used.

\section{Human Capital}

The first explanation of this inequality in the labour market highlights human capital, i.e. having a certain level and type of education, relevant work experience, on-the-job learning, being in good mental and physical health, and having proficiency in the required language(s). Migrants may possess less human capital and therefore have less access to (better paid) jobs and other forms of economic capital. This argument refers to migrants irrespective of nationality. Here, the place where one has acquired this human capital may make a difference: in the country of origin or the host country. The former may be rewarded less than the latter.

These sources of inequality seem quite harmless, since human capital requirements are functional to the work that needs to be done. Thus, mastering the right knowledge and skills is a legitimate reason for having more chances to get a job. However, that does not solve the problem, it mainly transfers it to the field of education. Migrants may have come here with lower levels of education, but may also have experienced exclusion in the educational system here. Moreover, there is a problem of getting one's foreign education credentials recognised, particularly for non-EU migrants and refugees. ${ }^{10}$

8 H. Siebers (2017), 'What turns migrants into ethnic minorities at work? Factors erecting ethnic boundaries among Dutch police officers', Sociology 51(3), pp. 6o8-625; A. Wimmer (2013), Ethnic Boundary Making. Institutions, Power, Networks, Oxford: Oxford University Press.

9 Migrancy status refers to whether one has a first- or second-generation migration background or having no such background.

10 T. de Lange, E. Besselsen, S. Rahouti, and C. Rijken (2017), Van azc naar een baan. De Nederlandse regelgeving over en praktijk van arbeidsmarktintegratie van vluchtelingen, Amsterdam: Universiteit van Amsterdam. 
In one of the organisations we studied, inequality in educational levels explains 24.5 percent of the lower chances that applicants with a 'nonWestern' migration background have of getting hired, compared to nonmigrant applicants. Here, ethno-migrant inequality in language proficiency and in tenure (proxy for the accumulation of relevant work experience) explains 41.1 per cent of ethno-migrant inequality in access to good jobs and corresponding salary scales. In yet another organisation, ethno-migrant inequality in levels of education and language proficiency explains 45.9 per cent of this inequality. ${ }^{11}$

\section{Social Capital}

Drawing on Bourdieu and Granovetter, ${ }^{12}$ a body of literature shows that ethno-migrant inequality may also be produced by unequal access to social capital. Having developed many weak ties, with influential people beyond your immediate social environment, is more effective for advancing in the labour market than having a smaller number of strong network ties within this environment. Migrants may rely on those strong or bonding ties when having arrived recently, especially in a not very hospitable society.

Ethno-migrant inequality in access to jobs due to migrants having fewer and weaker bridging ties is quite problematic. After all, getting a job with the help of someone in an influential position tells little about someone's capacity to perform a particular job properly. In principle, having social capital is not something job-related, unless having an extensive network of contacts is helpful in doing the job. If migrants face more difficulties to get hired due to having fewer network ties, without such network ties being instrumental for performing the job, we have a case of indirect discrimination.

In almost all organisations we studied, we found that people with a 'non-Western' migration background find it more difficult to network. To them, there is always the risk of becoming identified in ethnic terms, as a member of an ethnic minority. The fear associated with such risks affects their ability for networking for career purposes. Many feel hampered and uncomfortable in network activities, to move around in receptions and after-work drinks smoothly, and so on. They also feel uncomfortable when

11 H. Siebers and J. van Gastel (2015), 'Why migrants earn less: In search of the factors producing the ethno-migrant pay gap in a Dutch public organization', Work, Employment and Society 29(3), pp. 371-391.

12 P. Bourdieu (1986), 'The forms of capital', in J. Richardson (ed.) Handbook of Theory and Research for the Sociology of Education, Westport, CT: Greenwood; M. Granovetter (1983), 'The strength of weak ties: A network theory revisited', Sociological theory, 1(1) pp. 201-233. 
they need to make use of their network connections, such as gathering information about a particular vacancy they would like to apply for, or to mobilise support for themselves in general. In some organisations, the fear of becoming involved in ethnic conflicts becomes very real, actually triggering processes of exclusion against them. ${ }^{13}$

In one organisation, we found that 21 percent of the reasons why applicants with a 'non-Western' migration background have less chances for being hired is due to them having fewer contacts within that organisation that may help them in the application procedure. In another organisation, though, we found that such network effects were ruled out in application and promotion decisions due to very strict formalisation and accountability regulations. Such bureaucratic procedures may help to meet justice demands and to ensure that the best person gets the right job. ${ }^{14}$

\section{Direct Discrimination}

As indicated, the fact that migrants' lower levels of social capital make it more difficult for them to get a well-paid and satisfying job, indicates indirect discrimination. Direct discrimination is the case when nonmigrants avoid or reject migrants in their efforts to establish network ties with them. Direct discrimination is also the case when migrants' human capital is not recognised on equal terms as nonmigrants' human capital, or when migrants are underemployed, i.e. working on job levels below their human capital qualifications.

Many studies point to direct discrimination taking place in key personnel management activities. For example, there are many field experiments in which identical application letters are sent for vacancies, with only different names, indicating a migration background or not. Applications suggesting a migration background have a significantly lower chance of being invited for an interview, rather than those suggesting a nonmigrant background. ${ }^{15}$

13 H. Siebers (2017), 'What turns migrants into ethnic minorities at work? Factors erecting ethnic boundaries among Dutch police officers', Sociology, 51(3) pp. 6o8-625.

14 H. Siebers (2009), '(Post)bureaucratic organizational practices and the production of racioethnic inequality at work', Journal of Management and Organization, 15(1) pp. 62-81; H. Siebers (2010), 'Organisatiecultuur en verhulde discriminatie: Over het onthullen van discriminatie in hedendaagse organisaties', in C.J. Forder (ed.)(2009) Gelijke Behandeling: Oordelen en Commentaar, Nijmegen: Wolf Legal Publishers.; H. Siebers and J. van Gastel (2015), 'Why migrants earn less: In search of the factors producing the ethno-migrant pay gap in a Dutch public organization', Work, Employment and Society, 29(3) pp. 371-391.

15 E. Zschirnt and D. Ruedin (2016), 'Ethnic discrimination in hiring decisions: a meta-analysis of correspondence tests 1990-2015', Journal of Ethnic and Migration Studies, 42(7) pp. 1115-1134. 
There are also many case studies of discrimination in everyday interactions at work. ${ }^{16}$

Thus, direct discrimination may explain a substantial part of ethnomigrant inequality in the labour market, but what, in turn, explains direct discrimination? There are several theories that provide an explanation. There are racism theories that argue that racism drives discrimination. ${ }^{17}$ There are also sociopsychological explanations for discrimination that point to cognitive and affective processes of stereotyping and prejudices driving discriminatory behaviour. ${ }^{18}$

These explanations are not convincing for several reasons. Firstly, they tend to ignore one another. Racism scholars tend to conclude that it must be racism whenever migrants experience discrimination, without considering other possible explanations. They also often equate dependent and independent variables - discrimination is racism -; but then racism can no longer explain discrimination. It cannot be a dependent and independent variable simultaneously. ${ }^{19}$

In a similar way, sociopsychological studies conclude that, when field experiments demonstrate discrimination in the labour market, it must be driven by stereotyping and prejudices, but without empirically showing that this is the case. They draw on experimental research on stereotyping

For the Netherlands, see I. Andriessen, E. Nievers, L. Faulk, and J. Dagevos (2010), Liever Mark dan Mohammed? Onderzoek naar arbeidsmarktdiscriminatie van niet-westerse migranten via praktijktests, SCP; and L. Blommaert, F. van Tubergen, and M. Coenders (2012), 'Implicit and explicit interethnic attitudes and ethnic discrimination in hiring', Social Science Research, 41(1) pp. 61-73.

16 E.g. H. Siebers (2009), 'Struggles for Recognition: The Politics of Racioethnic Identity among Dutch National Tax Administrators', Scandinavian Journal of Management, 25(1) pp.,73-84; K. Van Laer and M. Janssens (2011), 'Ethnic minority professionals experiences with subtle discrimination in the workplace', Human Relations, 64(9) pp. 1203-1227.

17 For overviews, see L. Back and J. Solomos (eds.) (2009), Theories of Race and Racism. A Reader, London and New York: Routledge; Ph. Essed and D.Th. Goldberg (eds.) (2002), Race and Critical Theories, Oxford: Blackwell Publishers; P. Hill Collins and J. Solomos (2010),The SAGE Handbook of Race and Ethnic Studies, London: Sage.

18 For example, M. Chen and J.A. Bargh (1997), 'Nonconscious Behavioral Confirmation Processes: The Self-Fulfilling Consequences of Automatic Stereotype Activation', Journal of Experimental Social Psychology, 33(5) pp. 541-56o; N. Ellemers and M. Barreto (2008), 'Putting your own down: How members of disadvantaged groups unwittingly perpetuate or exacerbate their disadvantage', in A. Brief (ed.), Diversity at Work, Cambridge: Cambridge University Press; A.G. Greenwald, M.R. Banaji, L.A. Rudman, S.D. Farnham, B.A. Nozek, and D.S. Mellott (2002), 'A Unified Theory of Implicit Attitudes, Stereotypes, Self-Esteem, and Self-Concept', Psychological Review, $109(1)$ pp. 3-25.

19 H. Siebers (2017), "Race" versus "ethnicity"? Critical race essentialism and the exclusion and oppression of migrants in the Netherlands', Ethnic and Racial Studies, 4o(3) pp. 369-387. 
and prejudices, but experimental findings cannot simply be extrapolated to real-life settings in the labour market itself. These real-life settings are far more complicated than any experiment would be able to reconstruct.

Secondly, racism theories and sociopsychological explanations cannot explain variation in discrimination. Racism theories understand racism as a structural characteristic of the rise of modern societies. However, if defined as a trait of something as totalising as modernity, discrimination would have to be something that always happens, under all circumstances.

Likewise, sociopsychological explanations argue that people automatically create cognitive in-group and out-group classifications when they meet others whom they identify as belonging to another ethnic group. Due to the need for uncertainty reduction and self-esteem promotion, they tend to overestimate the traits of one's own category and underestimate outgroup traits, as social identity theory has it. Or people would have a natural tendency to prefer in-group members because they feel attracted to similar others, as similarity-attraction paradigm claims. Therefore, people would have a natural tendency to produce stereotypes, prejudices, and discriminatory behaviour towards out-group members. If creating stereotypes and prejudices is something people naturally do and if possibilities to control such creation are limited, ${ }^{20}$ discrimination would almost always have to occur.

The facts are different. As we found in our projects, in many day-to-day instances, migrant and nonmigrant colleagues cooperate very well most of the time. In the Netherlands, the vast majority of the migrant working population has found a job, independent of the help of fellow migrants. Ethnic identification does take place in some settings, but in other settings the very same people do not identify each other in ethnic terms but as colleagues. ${ }^{21}$ Identification processes and discrimination are much more variable than racism and sociopsychological theories assume.

\section{Nationalism}

There is another possible driver of direct discrimination: nationalism. So far, very little attention has been paid to it, ${ }^{22}$ whereas my own findings

20 E.g. B.D. Stewart and B.K. Payne (2008), 'Bringing Automatic Stereotyping Under Control: Implementation Intentions as Efficient Means of Thought Control', Personality and Social Psychology Bulletin, 34(10) pp. 1332-1345.

21 H. Siebers (2017), 'What turns migrants into ethnic minorities at work? Factors erecting ethnic boundaries among Dutch police officers', Sociology, 51(3) pp. 6o8-625.

22 For an exception, see R. Gowricharn and S. Çankaya (2015), 'Policing the Nation: Acculturation and Street-level Bureaucrats in Professional Life', Sociology, Epub ahead of print 29 September 
highlight its central role in fomenting direct discrimination in the labour market. ${ }^{23}$ Nationalism alludes to the impact of politics and here we need to distinguish between direct policy impact and its wider discursive impact.

Policy interventions and regulations may produce ethno-migrant inequality. Van Tubergen et al. ${ }^{24}$ have shown that guest workers' programmes in the 196os, deliberately selecting labour migrants for their low educational qualifications, hamper the labour market chances even for their children. Anderson ${ }^{25}$ has demonstrated how UK government policies are instrumental in reinforcing the precarity of migrant workers with a temporary work permit in the UK, as they need a recommendation letter from their employer to get their work permit renewed. Work permit schemes, such as the EU Blue Card, as well as the seasonal workers permit, discussed elsewhere in this volume, tie a migrant worker to a certain employer, specific sector, or specific job.

Politics also involves a wider discursive impact. From the 1980 s onwards, so-called 'non-Western' migrants have been identified by the Dutch government as 'ethnic minorities'. Until recently, ${ }^{26}$ this definition had a double foundation. On the one hand, these people are culturalised, ${ }^{27}$ i.e. understood as carriers of deviant cultural characteristics. On the other hand, they are understood as being in need for integration, i.e. find their place in societal institutions like the labour market.

At first, their cultural and ethnic identity were seen as beneficial to their participation in society. Some modest policies were initiated to support

2016. DOI: $10.1177 / 0038038515601781$.

23 H. Siebers (2010), 'The Impact of Migrant-Hostile Discourse in Media and Politics on Racioethnic Closure in Career Development in The Netherlands', International Sociology, 25(4) pp. 475-500; H. Siebers (2017), 'What turns migrants into ethnic minorities at work? Factors erecting ethnic boundaries among Dutch police officers', Sociology, 51(3) pp. 6o8-625; P. Mutsaers, H. Siebers, and A. de Ruijter (2014), 'Becoming a Minority: Ethno-Manufacturing in the Netherlands', in J. Tripathy and S. Padmanabhan (eds.), Becoming Minority: How Discourses and Policies Produce Minorities in Europe and India, New Delhi: Sage.

24 F. van Tubergen, I. Maas, and H. Flap (2004), 'The economic incorporation of immigrants in eighteen western countries: Origin, destination, and community effects', American Sociological Review, 69(5) pp. 704-727.

25 B. Anderson (2010), 'Migration, immigration controls and the refashioning of precarious workers', Work, Employment and Society, 24(2) pp. 300-317.

26 M. Bovens, M. Bokhorst, R. Jennissen, and G. Engbersen (2016), Migratie en classificatie: naar een meervoudig migratie-idioom, Den Haag: Wetenschappelijke Raad voor het Regeringsbeleid. 27 J.W. Duyvendak, P. Geschiere, and E. Tonkens (2016), The Culturalization of Citizenship. Belonging and Polarization in a Globalizing World, London: Palgrave Macmillan.; H. Siebers (20o9), 'Registreren van etniciteit is spelen met vuur', Openbaar Bestuur, 19(2) pp. 2-6; H Siebers and M.H.J. Dennissen (2015), 'Is it cultural racism? Discursive oppression and exclusion of migrants in the Netherlands', Current Sociology, 63(3) pp. 470-489. 
this identity, such as education in their own language and culture. The government acknowledged a joint responsibility to facilitate their ways into the labour market. Until 2004, the Stimulering Evenredige Arbeidsdeelname Minderheden (SAMEN) law obliged organisations and companies to file reports annually on their efforts to let their labour force be a reflection of the regional demographic composition.

However, Wimmer and Glick Schiller ${ }^{28}$ remind us that the ethnicisation of migrants usually takes place within the construction of nationalism. Nationalism invents categorical distinctions between nationals and outsiders, distinctions that subsequently develop into boundaries. By framing 'non-Western' migrants as ethnic groups, they were turned into the outsiders within. In the 199os, this nationalist approach took on a civic form, ${ }^{29}$ with emphasis on creating the conditions for participation in society, like the labour market.

However, since the turn of the century, nationalism has shifted in an ethno-nationalist direction ${ }^{30}$ in which assumed Dutchness has become the standard in public discourse and policies. ${ }^{31}$ The same previous two aspects of the definition of ethnic minorities, assumedly being culturally different and needing societal integration, have reappeared in a new articulation. On the one hand, assumed cultural traits of 'non-Western' migrants are seen as incompatible with assumed Dutch values. ${ }^{32}$ On the other hand, these assumed incompatible cultural traits are held responsible for their poor levels of integration in society. Their exclusion is justified, arguing that their cultural traits are incompatible with assumed Dutchness and that they have poor prospects for participation in society anyway.33

This means blaming the victims. The nationalist 'othering' of migrants triggers exclusion processes and symbolic violence against people with a 'non-Western' migration background. The contents of the stigmas and

28 A.Wimmer and N. Glick Schiller (2002), 'Methodological nationalism and beyond: Nation-state building, migration and the social sciences', Global Networks, 2(4) pp. 301-334.

29 E. Gellner (1983), Nations and Nationalism, Ithaka, NY: Cornell University Press.

30 A.D. Smith (1986), The Ethnic Origins of Nations, Oxford: Blackwell.

31 R. van Reekum (2012), 'As nation, people and public collide: enacting Dutchness in public discourse', Nations and Nationalism, 18(4) pp. 583-602; R. van Reekum and J.W. Duyvendak (2012), 'Running from our shadows: the performative impact of policy diagnoses in Dutch debates on immigrant integration', Patterns ofJustice, 46(5) pp. 445-466.

32 S. Suvarierol (2012), 'Nation-freezing: images of the nation and the migrant in citizenship packages', Nations and Nationalism, 18(2), pp. 210-229.

33 H. Siebers and M.H.J. Dennissen (2015), 'Is it cultural racism? Discursive oppression and exclusion of migrants in the Netherlands', Current Sociology, 63(3) pp. 470-489; S. Bonjour and J.W. Duyvendak (2017), 'The "migrant with poor prospects": racialized intersections of class and culture in Dutch Civic integration debates', Ethnic and Racial Studies. DOI: 10.1080/01419870.2017.1339897. 
meanings that incite acts of discrimination in the organisations we studied exclusively reflect the negative connotations that the nationalist discourse in Dutch media and politics attributes to 'non-Western' migrants, such as their assumed involvement in crime, in terrorism, and in gender- and sexualityrelated violence. These nationalist stigmas are adopted by nonmigrants and trigger conflicts and exclusion against people with a 'non-Western' migration background in work settings, with negative consequences for the latter's careers and payment. ${ }^{34}$

To give a few examples, one of our female respondents with a Moroccan background heard from her nonmigrant colleagues when she went to an after-work party, 'Were you allowed off the chain this evening?'. Muslim employees have to answer questions from colleagues about why Islam incites terrorism, apparently suggesting they have something to do with it. A civil servant with a Surinamese background, working for the government supported by the nationalist PVV party, was told by her colleagues, after she was turned down for a promotion, 'Where do your sort of people get the courage from to apply for such a job?'. A police officer with a Turkish background was informed about the reasons why she did not get promoted to a managerial job, 'You and me, we have been at war for centuries already'. Here, the nonmigrant selector reproduced images of cultural incompatibility and nationalist confrontations propagated by nationalist politicians.

The nationalist framing of particular categories of migrants as 'ethnic minorities' also creates feelings of insecurity on the part of these migrants when trying to network or use their social capital. An employee with a 'non-Western' migration background who did manage to get promoted to a supervision post, at the start of team meetings, deliberately displayed a screen saver with a picture of his children. This was an attempt to remind his colleagues of the fact that he is a human being after all. He was compelled to do this when they tended to simply ignore him. Eventually, he had to be transferred to a nonmanagerial job.

The contents of these discrimination-inciting stigmas, stemming from Dutch nationalist discourses in media and politics, also explain part of the variability in direct discrimination. In organisations in which the primary process is closely linked to these contents, we see overt and blunt events of discrimination taking place. For example, in the Dutch police force, the association of 'non-Western' migrants with crime, in nationalist discourses

34 H. Siebers (2010), 'The Impact of Migrant-Hostile Discourse in Media and Politics on Racioethnic Closure in Career Development in The Netherlands', International Sociology, 25(4) pp. 475-500. 
in media and politics, creates suspicion towards officers with a 'non-Western' background and triggers incidents of discrimination against them. Crime fighting is a core business of the Dutch police. ${ }^{35}$ By contrast, no such incidents took place in the former Dutch ministry of agriculture, since there is no connection between the ministry's work and these nationalist stigmas. ${ }^{6}$

\section{Cultural Capital: 'soft skills'}

My second contribution to understanding ethno-migrant inequality in the labour market refers to the role of so-called 'soft skills'. It builds upon what Alvesson and Willmott ${ }^{37}$ have coined as identity regulation or socioideological labour control. It means that job applicants and workers are no longer only assessed on input (human capital) and output (quantity and quality of one's work and the observance of regulations and protocols), but also on the ways in which they perform their work and with which personality traits. These personality traits are often phrased as attitudes and 'soft skills' (being enthusiastic, motivated, communicative, proactive, assertive, authentic, creative, flexible, etc.).

All the organisations that we studied have introduced these kinds of selection and assessment criteria. Nevertheless, their functionality is often very questionable. Most of the time, HR advisors and supervisors were unable to answer our question about why these qualifications are necessary for achieving the work targets and results. Why should a tax administrator, whose job it is to control tax files, be creative? Why is a police officer supposed to be authentic? In addition, what is the surplus value for controlling how one achieves his or her targets, if the targets themselves are already assessed?

The processes to be achieved by requiring soft skills from employees, like open and fluent communication, are basically social processes. It has become fashionable to rephrase traits of social relations into personal or psychological traits, ${ }^{38}$ but this cannot be done without serious distortions.

35 H. Siebers, (2017), 'What turns migrants into ethnic minorities at work? Factors erecting ethnic boundaries among Dutch police officers', Sociology 51 (3) 608-625.

36 H. Siebers and J. van Gastel, (2015), 'Why migrants earn less: In search of the factors producing the ethno-migrant pay gap in a Dutch public organization', Work, Employment and Society 29(3) 371-391.

37 M. Alvesson and H. Willmott (2002), 'Identity regulation as organizational control: producing the appropriate individual', Journal of Management Studies, 39(5) pp. 619-644.

38 K.T. DiFruscia (2012), 'Work Rage: The Invention of a Human Resource Management AntiConflictual Fable', Anthropology of Work Review 33(2) pp. 89-100. 
For example, it is inappropriate to lay the responsibility for good communication processes unilaterally on the shoulders of individual applicants and employees. One could just as well argue that it is the responsibility of an organisation to ensure that someone with the right human capital is able to work effectively and communicatively.

Thus, I argue that these 'soft skills' or personality prescriptions do not qualify as human capital, but as cultural capital. They are about cultural issues of identity construction and the presentation of self in everyday life. 39 They are resources for individuals to profile and distinguish themselves from others, to create distinction framed as higher valued culture. ${ }^{40}$ They become capital if people manage to infer the suggestion that they possess a scarce and valued property that can be used to access economic capital. Bourdieu ${ }^{41}$ shows that those who can claim to possess cultural capital are not worried about its functionality; those worries are only expressed by those with less such capital.

In all the organisations we studied, competition over soft skills, such as cultural capital in selection and promotion procedures, constitutes one of the main factors producing ethno-migrant inequality. Applicants and employees with a 'non-Western' migration background encounter serious problems whilst profiling themselves in these terms, which reduces their chances for getting hired or promoted. In one of these organisations, this factor is responsible for 47.4 per cent of their lower chances for getting hired.

Next, in general, applicants and employees with a 'non-Western' migration background try to perform on human capital or job-related criteria. They profile their human capital in application procedures and perform in terms of quantity and quality of results. However, they are basically assessed on criteria that apply to the cultural field. Non-migrant applicants and employees are more aware of these real assessment criteria and focus more on those in application and assessment interviews. Thus, there is a mismatch between criteria that applicants and employees with a 'non-Western' migration background focus on, and the real criteria by which they are assessed, by their predominantly non-migrant selectors and supervisors.

In addition, human capital can be assessed in relatively objective terms, by checking one's diplomas and relevant work experience. By contrast, 'soft skills' requirements are much more vague and ambiguous. There is no clear 
relationship between the linguistic sign of, for example, 'creativity' and the processes in reality to which the sign would refer. Criteria such as having to be 'authentic' are highly ambiguous. In other words, 'soft skills' suffer from denotational indeterminacy, which opens the door for their strategic use against people with a 'non-Western' migration background..$^{42}$

As a result, assessments of an applicant's or employee's 'soft skills' can only be made drawing on the assessor's subjective interpretations and impressions. Assessments in the cultural field are a matter of taste, Bourdieu ${ }^{43}$ argues, in which the above-mentioned negative images about migrants in political and media discourse can easily become salient. Selectors told us that they base their assessment on the impression they get from an applicant in the first seconds of the interview. Thus, the applicant who is identified as someone with a 'non-Western' migration background is at a disadvantage because such an identification can easily trigger the negative connotations nationalist discourses in media and politics attribute to such people. They have a double burden: they not only need to show that they have the right human capital, but also that they are properly assimilated in the cultural field.

This symbolic violence in assessing cultural capital at the cost of a particular group is legitimised in a culturalist way. In line with nationalist discourses, selectors and supervisors attribute the lower scores of migrant applicants and employees based on 'soft skills', such as assertiveness, communicativeness, and proactiveness, to the cultural backgrounds of these applicants and employees. They tend to bring values of modesty and reactive attitudes to work from their cultural backgrounds, which apparently are incompatible with what is demanded from them at work, just like the current nationalist discourse argues that 'values' 'non-Western' migrants would cherish would be incompatible with 'Dutch values'. The question whether people with such diverse cultural backgrounds, stemming from very different parts of the world, would all have those same 'non-Western' values in common, is not raised.

It is much more likely that less proactive or assertive behaviour stems from the latent or overt insecurity these people have in common, due to fact that they have become the object of nationalist discourses. It is hard

42 H. Siebers (2017), 'What turns migrants into ethnic minorities at work? Factors erecting ethnic boundaries among Dutch police officers', Sociology, 51(3) pp. 6o8-625; B. Urciuoli (2008), 'Skills and selves in the new workplace', American Ethnologist, 35(2) pp. 211-228.

43 P. Bourdieu (1984), Distinction: A Social Critique of the Judgement of Taste, Boston: Harvard University Press. 
to become proactive and assertive if you do not feel secure. ${ }^{44}$ By introducing criteria for control and assessment that belong to the cultural field, discourses that are active and appropriate in that cultural field come to determine outcomes of the struggle for capital. The application of 'soft skills', i.e. cultural capital, as criteria for assessment and control, allows nationalist discourses on migrants and migration to land at the gate and on the work floor of organisations, so to speak, to erect boundaries between applicants and employees with a 'non-Western' migration background and those without a migration background, producing ethno-migrant inequality in Dutch public organisations.

Migrants are instructed on assumedly Dutch 'soft skills' in civic integration programmes ${ }^{45}$, and Dutch authorities such as COA make a lot of effort to train refugees in Dutch 'soft skills, ${ }^{46}$ but that seems like an uphill battle. It would be far more fruitful to stop assessing applicants and employees based on their 'soft skills' altogether. Assessing applicant and employees on their 'soft skills' represents a clear example of indirect discrimination, as these skills are not job-related and work out disproportionately negatively for people with a 'non-Western' migration background.

\section{Conclusion}

Ethno-migrant inequality in access to economic capital in the labour market may be produced by several factors, including unequal access to human capital and social capital, direct discrimination, the impact of nationalist discourses, and the competition over cultural capital through the introduction of 'soft skills' as criteria for selection and assessment. In theory, sociopsychological factors and racism may also contribute to ethnomigrant inequality through triggering discriminatory behaviour. However, in the Dutch case, explanations referring to them are not convincing, which

44 Efforts like those by Geert Hofstede to pinpoint 'cultures' to specific traits ('Dutch culture is[...]') in a globalized world have been unsuccessful for various conceptual and methodological reasons. I argue that it is more likely that both assertive and nonassertive behaviour, for example, are present in and available from each and every cultural repertoire and that it is the context that renders one salient and not the other. That means that context matters, in this case, insecurity, not the cultural repertoires as such.

45 S. Suvarierol (2012), 'Nation-freezing: images of the nation and the migrant in citizenship packages', Nations and Nationalism, 18(2) pp. 210-229.

46 T. de Lange, E. Besselsen, S. Rahouti, and C. Rijken (2017), Van azc naar een baan. De Nederlandse regelgeving over en praktijk van arbeidsmarktintegratie van vluchtelingen, Amsterdam: Universiteit van Amsterdam. 
does not rule out their salience and relevance elsewhere. Individual cases of ethno-migrant inequality on the macro, meso, and micro levels may be produced by different mixes of the factors discussed above. They are very historical, contextual, and thus variable. The explanatory framework set out here will, however, be helpful in analysing individual cases to produce those different results and to avoid biases and blind spots. With those results, much needed recommendations can be made for changing macro government policies and discourses, management and intervention approaches on the organisational level, and expectations and strategies taken by individual actors. These are good reasons for being prudent in developing national and macro level policies and focussing on individual sectors and organisations instead. The framework is far from perfect, though. More research is needed, in particular on how those various factors and explanations interrelate and articulate.

\section{Bibliography}

Alvesson, M. and H. Willmott (2002), 'Identity regulation as organizational control: producing the appropriate individual', Journal of Management Studies, 39(5) pp. 619-644.

Anderson, B. (2010), 'Migration, immigration controls and the refashioning of precarious workers, Work', Employment and Society, 24(2) pp. 300-317.

Back, L. and J. Solomos (eds.) (2009), Theories of Race and Racism. A Reader, London and New York: Routledge.

Blommaert, L.; F. van Tubergen; and M. Coenders (2012), 'Implicit and explicit interethnic attitudes and ethnic discrimination in hiring', Social Science Research, 41(1) pp. 61-73.

Bonjour, S. and J.W. Duyvendak (2017), 'The "migrant with poor prospects": racialized intersections of class and culture in Dutch Civic integration debates', Ethnic and Racial Studies Epub. DOI: 10.1080/01419870.2017.1339897, pp.1-20.

Bourdieu, P. (1977), Outline of theory of practice, Cambridge: Cambridge University Press.

Bourdieu, P. (1984), Distinction: A Social Critique of the Judgement of Taste, Boston: Harvard University Press.

Bourdieu, P. (1984), 'Social space and symbolic power', Sociological Theory, 7(1) pp. 14-25.

Bourdieu, P. (1986), 'The forms of capital', in J. Richardson (ed.), Handbook of Theory and Research for the Sociology of Education, Westport, CT: Greenwood. 
Bovens, M.; M. Bokhorst; R. Jennissen; and G. Engbersen (2016), Migratie en classificatie: naar een meervoudig migratie-idioom, Den Haag: Wetenschappelijke Raad voor het Regeringsbeleid.

CBS (2016), Jaarrapport Integratie 2016, Den Haag/Heerlen: Centraal Bureau voor de Statistiek.

Chen, M. and J.A. Bargh (1997), 'Nonconscious Behavioral Confirmation Processes: The Self-Fulfilling Consequences of Automatic Stereotype Activation', Journal of Experimental Social Psychology, 33(5) pp. 541-56o.

DiFruscia, K.T. (2012), 'Work Rage: The Invention of a Human Resource Management Anti-Conflictual Fable', Anthropology of Work Review, 33(2) pp. 89-100.

Duyvendak,J.W.; P. Geschiere; and E. Tonkens (2016), The Culturalization of Citizenship. Belonging and Polarization in a Globalizing World, London: Palgrave Macmillan.

Ellemers, N. and M. Barreto (2008), 'Putting your own down: How members of disadvantaged groups unwittingly perpetuate or exacerbate their disadvantage', in A. Brief (ed.), Diversity at Work, Cambridge: Cambridge University Press.

Essed, P., and D.T. Goldberg (eds.) (2002), Race and Critical Theories, Oxford: Blackwell Publishers.

Gellner, E. (1983), Nations and Nationalism, Ithaka, NY: Cornell University Press.

Goffman, E. (1959), The Presentation of Self in Everyday Life, New York: Random House.

Gowricharn, R. and S. Çankaya (2015), 'Policing the Nation: Acculturation and Street-level Bureaucrats in Professional Life', Sociology Epub. DOI: $10.1177 / 0038038515601781$.

Granovetter, M. (1983), 'The strength of weak ties: A network theory revisited', Sociological theory, 1(1) pp. 201-233.

Greenwald, A.G.; M.R. Banaji; L.A. Rudman; S.D. Farnham; B.A. Nozek; and D.S. Mellott (2002), 'A Unified Theory of Implicit Attitudes, Stereotypes, Self-Esteem, and Self-Concept', Psychological Review, 109(1), pp. 3-25.

Heath, A. and S.Y. Cheung (2007), Unequal Chances: Ethnic Minorities in Western Labour Markets, Oxford: Oxford University Press.

Hill Collins, P. and J. Solomos (2010), The SAGE Handbook of Race and Ethnic Studies, London: Sage.

Laer, K. van and M. Janssens (2011), 'Ethnic minority professionals experiences with subtle discrimination in the workplace', Human Relations, 64(9) pp.1203-1227.

Lange, T. de; E. Besselsen; S. Rahouti; and C. Rijken (2017), Van azc naar een baan. De Nederlandse regelgeving over en praktijk van arbeidsmarktintegratie van vluchtelingen, Amsterdam: Universiteit van Amsterdam.

Mutsaers, P.; H. Siebers; and A. de Ruijter (2014), 'Becoming a Minority: EthnoManufacturing in the Netherlands', in J. Tripathy and S. Padmanabhan (eds.), 
Becoming Minority: How Discourses and Policies Produce Minorities in Europe and India, New Delhi: Sage.

Reekum, R. van (2012), 'As nation, people and public collide: enacting Dutchness in public discourse', Nations and Nationalism, 18(4) pp. 583-6o2.

Reekum, R. van and J.W. Duyvendak (2012), 'Running from our shadows: the performative impact of policy diagnoses in Dutch debates on immigrant integration', Patterns ofJustice, 46(5) pp. 445-466.

Siebers, H. (2009) '(Post)bureaucratic organizational practices and the production of racioethnic inequality at work', Journal of Management and Organization, 15(1) pp. 62-81.

Siebers, H. (2009), 'Registreren van etniciteit is spelen met vuur', Openbaar Bestuur, 19(2) pp. 2-6.

Siebers, H. (2009), 'Struggles for Recognition: The Politics of Racioethnic Identity among Dutch National Tax Administrators', Scandinavian Journal of Management, $25(1)$ pp. $73-84$.

Siebers, H. (2010), 'Organisatiecultuur en verhulde discriminatie: Over het onthullen van discriminatie in hedendaagse organisaties', in C.J. Forder (ed.), Gelijke Behandeling: Oordelen en Commentaar 2009, Nijmegen: Wolf Legal Publishers.

Siebers, H. (2010), 'The Impact of Migrant-Hostile Discourse in Media and Politics on Racioethnic Closure in Career Development in The Netherlands', International Sociology, 25(4) pp. 475-500.

Siebers, H. (2017), 'What turns migrants into ethnic minorities at work? Factors erecting ethnic boundaries among Dutch police officers', Sociology, 51(3) pp. 608-625

Siebers, H. (2017), "Race" versus "ethnicity"? Critical race essentialism and the exclusion and oppression of migrants in the Netherlands', Ethnic and Racial Studies, 4o(3) pp. 369-387.

Siebers, H. and M.H.J. Dennissen (2015), 'Is it cultural racism? Discursive oppression and exclusion of migrants in the Netherlands', Current Sociology, 63(3) pp. 470-489.

Siebers, H. and J. van Gastel (2015), 'Why migrants earn less: In search of the factors producing the ethno-migrant pay gap in a Dutch public organization', Work, Employment and Society, 29(3) pp. 371-391.

Smith, A.D. (1986), The Ethnic Origins of Nations, Oxford: Blackwell.

Stewart, B.D. and B.K. Payne (2008), 'Bringing Automatic Stereotyping Under Control: Implementation Intentions as Efficient Means of Thought Control', Personality and Social Psychology Bulletin, 34(10) pp. 1332-1345.

Suvarierol, S. (2012), 'Nation-freezing: images of the nation and the migrant in citizenship packages', Nations and Nationalism, 18(2) pp. 210-229. 
Tubergen, F. van; I. Maas; and H. Flap (2004), 'The economic incorporation of immigrants in eighteen western countries: Origin, destination, and community effects', American Sociological Review, 69(5) pp. 704-727.

Urciuoli, B. (2008), 'Skills and selves in the new workplace', American Ethnologist, 35(2) pp. 211-228.

Wimmer, A. (2013), Ethnic Boundary Making. Institutions, Power, Networks, Oxford: Oxford University Press.

Wimmer, A. and N. Glick Schiller (2002), 'Methodological nationalism and beyond: Nation-state building, migration and the social sciences', Global Networks, 2(4) pp. 301-34.

Zschirnt, E. and D. Ruedin (2016), 'Ethnic discrimination in hiring decisions: a meta-analysis of correspondence tests 1990-2015',Journal of Ethnic and Migration Studies, 42(7) pp. 1115-1134.

\section{About the Author}

Hans Siebers is an associate professor at Tilburg School of Humanities and Reflect: Research institute for flexicurity, labour market dynamics, and social cohesion at Tilburg University. 